\title{
Water quality and fish diversity in Korotoa River of Bogura, Bangladesh
}

\author{
SAMINA AHATUN, MD. SIRAJUL ISLAM*, MD. HUMAYUN KABIR, \\ MAUSUMI REHNUMA AND MD. ENAMUL HOQ ${ }^{1}$, \\ Department of Environmental Science \& Resource Management, \\ Mawlana Bhashani Science and Technology University, Tangail 1902, Bangladesh \\ ${ }^{1}$ Bangladesh Fisheries Research Institute, Mymensingh 2201, Bangladesh \\ *Email: islammstazu@yahoo.com
}

\begin{abstract}
The study was conducted to explore the physicochemical parameters of water, fish diversity and fisheries resources of Korotoa River at Bogura city of Bangladesh during July 2015 to February 2016. The water samples were collected from five sampling stations in the Korotoa River during wet and dry seasons. The results of the study showed that temperature, EC, TDS, DO, BOD, alkalinity, acidity and total hardness of the Karotoa River water were $25.86^{\circ} \mathrm{C}, 297.41 \mu \mathrm{S} / \mathrm{cm}, 98.86 \mathrm{mg} / \mathrm{L}, 2.17 \mathrm{mg} / \mathrm{L}, 2.64 \mathrm{mg} / \mathrm{L}, 122.05$ $\mathrm{mg} / \mathrm{L}, 3.28 \mathrm{mg} / \mathrm{L}$ and $75.59 \mathrm{mg} / \mathrm{L}$, respectively. The DO and BOD contents of the river water were found unsuitable for fisheries when compared with the standard of DoE. A total of ten fish species under six orders and seven families were identified during the study period. The study also revealed that the most remarkable cause of water quality degradation of the river was waste dumping (58\%) followed by urbanization and river bank erosion. The water quality degradation $(46 \%)$ negatively influenced the abundance of fish species. The results concluded that the water quality of the river is not favorable for production of fishes and other aquatic organisms. The study suggested that the source of water quality degradation should be closely monitored together with the industrial effluent and/or domestic sewage discharge should be reduced or stopped through the initiatives of the local government concerned to maintain sound and healthy ecosystem of the river.

Keywords: Water quality, Korotoa River, Wet and dry season
\end{abstract}

\section{Introduction}

Water is the most vital element among the natural resources and is crucial for the survival of all aquatic organisms (Hasan et al. 2014). The surface water is very much essential for any country because of its human and animal living, aquatic flora and fauna, navigation, agriculture, etc. (Hasan et al. 2015). Rivers are important features of Bangladesh's landscape where hundreds of rivers are crisscrossing the landmass and playing role of artery and veins for the maintenance of the ecosystem of the country. Rivers are mainly used for irrigation, fisheries, drinking water, navigation and industrial purposes. The volumes of water they carry vary widely depending on the season, heavy summer rainstorms, upstream diversion of water flow and dry winter months (DoE 2016). But it is unfortunate that the human activities everywhere in the world are continuously polluting water. The surface water qualities of the rivers of Bangladesh are getting highly polluted day by day (DoE 2016). River pollution has been a major problem in the developing countries (Hasan et al. 2014). The increasing population, urbanization, industrialization and agricultural practices of Bangladesh have negative implications on water quality. Fishes are invariable living components of water bodies. These organisms are important food resources and good indicators of the ecological health of the waters they inhabit. However, the rich biodiversity of the freshwater fish of Bangladesh has been rapidly dwindling because of increasing degradation of inland water. As because of different natural and human intervention, the rivers of Bangladesh have been losing their fish biodiversity gradually (Khan et al. 2013). So 
the actual available fish species of the river should be known to conserve its natural biodiversity (Rubel et al. 2014).

The Korotoa River is one of the major rivers in Bangladesh. Over the centuries, the river is not only lost its water flow due to various natural causes but most of its parts on both sides have also been encroached. Presently it like many other rivers are at the risk of partial or total degradation due to manifold reasons like agricultural encroachment including pesticide usage, siltation along with other anthropogenic activities (Sayeed et al. 2014). Thousands of villages, towns and commercial places like Mohasthangarh, Bogura, and Sherpur were built on the west bank of the Korotoa River along its $200 \mathrm{~km}$ path. Agriculture, aquaculture, and fishing are the primary activities of the people living beside this river. This river receives domestic raw sewage, household waste, and industrial waste from surrounding habitation. During the last decades, natural and human activities have caused a complete deterioration of the river ecosystems (Proshad et al. 2018). The physiochemical parameters are very important because they have a significant effect on the aquatic environment where aquatic life as well as fishes suffers due to the degradation of water quality (Proshad $e t$ al. 2018). Therefore, various studies have been carried out on the physicochemical water qualities in different rivers in Bangladesh but the physicochemical water parameters along with the fish diversity in the Korotoa River have not been investigated, except investigation showed that the toxic metals contamination in surface water and sediment of the river (Proshad et al. 2018). In this regard, the study was conducted to know the present scenario of the urban river and make a future direction to improve the quality of the river in all aspects. The objectives of this study were to investigate the water quality parameters (temperature, EC, TDS, DO, BOD, alkalinity, acidity and total hardness), to know the present status of fish diversity, and to find out the major causes of water quality degradation of the Korotoa River which expected to provide the basic information to the concerned authority for the management of the river water quality in Bangladesh.

\section{Materials and Methods}

Study area: The study was conducted in the Korotoa River at the sadar upazila of Bogura district, located at the northern part of Bangladesh during July 2015 to February 2016 (Fig. 1). The study area was located in latitude of $26^{\circ} 15^{\prime} \mathrm{N}$ and longitude of $88^{\circ} 39^{\prime} \mathrm{E}$. The Korotoa River was originated in the Himalayas, the mother of numerous rivers. Originating from northern frontier of Bhutan, the Korotoa enters into Bangladesh territory through Darjeeling and Jalpaiguri districts of West Bengal in India, and forms for some distance the boundary between Dinajpur and Rangpur districts, Bangladesh. The area of Bogura district is about $71.56 \mathrm{~km}^{2}$ and the total population of this district is about 350,397 (Proshad et al. 2018). The Mohasthangarh, the capital of ancient Pundranagar is still there beside the river as a witness of history in Bangladesh. The study was carried out through laboratory experiments and social survey systems.

Water sample collection and analysis: The water samples were collected from five different sampling stations in the Korotoa River namely Nawdapara (St-1), Matidali (St-2), Muglishpur (St-3), Fulbari (St-4) and Chalopara (St-5) with distance of $1 \mathrm{~km}$ from each other covering the period of wet (July 2015 to September 2015) and dry (December 2015 to February 2016) seasons (Fig. 1). The sampling stations were selected on the basis of topography, vegetation, easy communication and availability of the samples. Samples were collected by $500-\mathrm{ml}$ plastic 
WATER QUALITY AND FISH DIVERSITY IN KOROTOA RIVER

bottles with double stoppers from each sampling station. Prior to collection, the bottles were cleaned by detergent solution and treated with $5 \%$ nitric acid $\left(\mathrm{HNO}_{3}\right)$ overnight. The bottles were finally washed with deionized water followed by repeated washing with sample water so as to avoid contamination. After sampling, the bottles were screwed carefully, labeled properly for identification, brought to the laboratory and preserved carefully until analysis. The physicochemical properties of water such as temperature, electric conductivity (EC), total dissolved solid (TDS), dissolved oxygen (DO), biological oxygen demand (BOD), alkalinity, acidity and total hardness were determined in the Ecology Laboratory of the Department of Environmental Science and Resource Management, Mawlana Bhashani Science and Technology University following the well-established analytical methods stated in Table I.

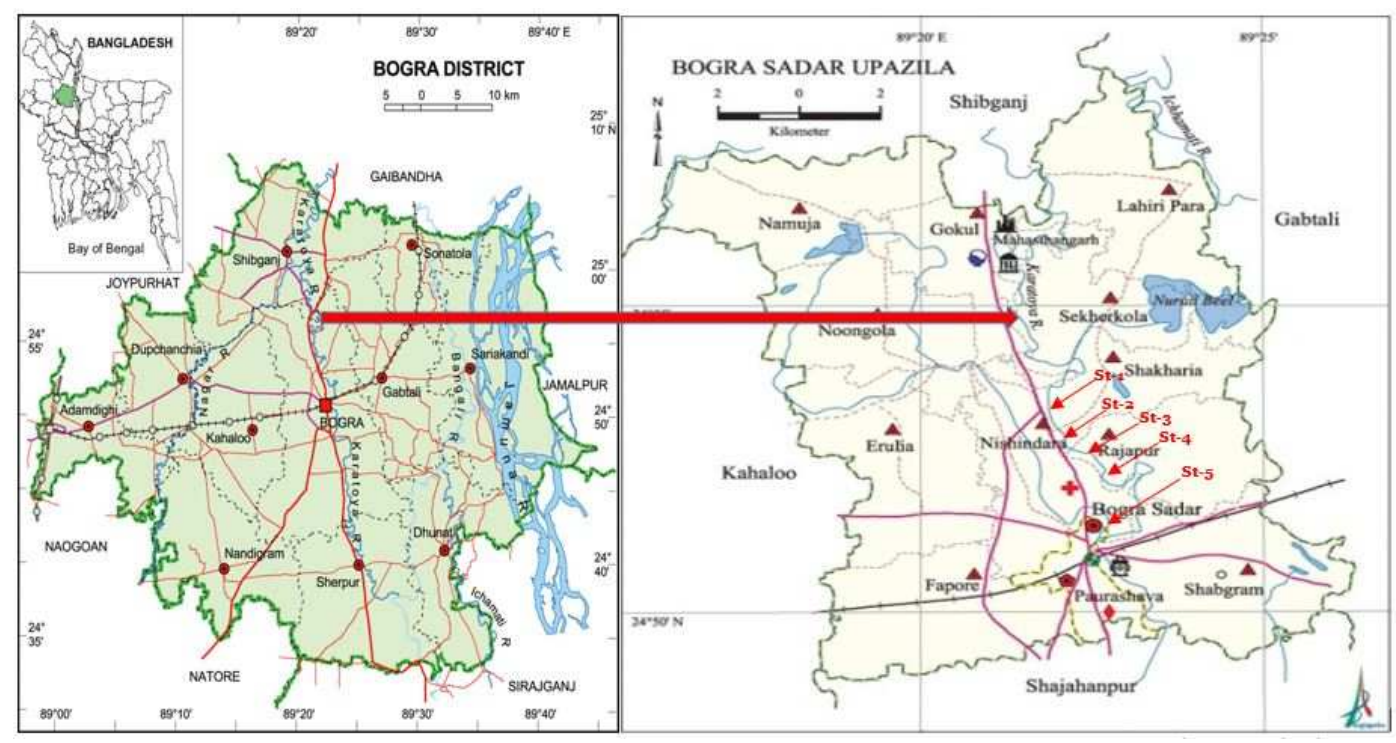

Fig. 1. Map showing the sampling stations in Korotoa River of Bogura, Bangladesh.

Fish sample collection and identification: Fish samples were collected randomly from fishermen by using fish cust net from the above mentioned sampling stations in the Korotoa River (Fig. 1). After collection, fish samples were preserved in formalin (5 to 10\%) and brought to the laboratory of the Department of Environmental Science and Resource Management, Mawlana Bhashani Science and Technology University for identification. Preserved specimens were identified/ classified according to their morphometric and meristic characteristics with the help of the following documents: Freshwater Fishes of Bangladesh (Rahman 2005), FAO species identification guide for fishery purposes (Carpenter and Niem 1998), Red List of Bangladesh, (IUCN 2015), and previous studies (Islam et al. 2016, Galib et al. 2013).

Social survey. The societal data about the present situation of the Korotoa River, its fish diversity, degradation of water quality and loss of fish species and fisheries resources was collected from local people and stakeholders by questionnaire survey. A total of 50 respondents who are directly and indirectly dependent on the river for their livelihood were surveyed from the study area. 
SAMINA AHATUN et al.

Table I. Water quality parameters, methods and instruments used for analysis

\begin{tabular}{lcc}
\hline Parameters & Units & Methods and instruments used \\
\hline Temperature & ${ }^{\circ} \mathrm{C}$ & Thermometer (Celsius scale), directly in the field \\
EC & $\mu \mathrm{S} / \mathrm{cm}$ & Digital EC meter (Model: HM digital, Germany) \\
TDS & $\mathrm{mg} / \mathrm{L}$ & Digital TDS meter (Model: HM digital, Germany) \\
DO & $\mathrm{mg} / \mathrm{L}$ & Digital DO meter (Model: D.46974, Taiwan) \\
BOD & $\mathrm{mg} / \mathrm{L}$ & Incubation method (BOD = BOD 1 -DO5) \\
Alkalinity & $\mathrm{mg} / \mathrm{L}$ & Titration method \\
Acidity & $\mathrm{mg} / \mathrm{L}$ & Titration method \\
Total hardness & $\mathrm{mg} / \mathrm{L}$ & Titration method \\
\hline
\end{tabular}

Statistical analysis: The collected data were compiled, tabulated and analyzed in proper form subjected to statistical analysis. Statistical analysis was done with the help of Microsoft Office Excel (2010) and Statistical Package for Social Science (SPSS, IBM 20.0) software (mean, standard deviation, etc.). Finally the analyzed data were integrated and presented in charts and tabular forms.

\section{Results and Discussion}

\section{Water quality parameters}

Temperature: The average temperature of Korotoa River water was $25.86^{\circ} \mathrm{C}$ which is within the standard $\left(20\right.$ to $\left.30^{\circ} \mathrm{C}\right)$ for aquatic medium. Temperature of the Korotoa River water reflects that it changed with time and seasons. In wet season, the highest $\left(32.6^{\circ} \mathrm{C}\right)$ and the lowest temperature $\left(32.1^{\circ} \mathrm{C}\right)$ were found at St-2 and St-4, and St-5, respectively (Table II). The highest temperature $\left(19.8^{\circ} \mathrm{C}\right)$ was found at St-2 and the lowest $\left(18.9^{\circ} \mathrm{C}\right)$ was at St-4 in dry season. The mean water temperature $\left(32.35^{\circ} \mathrm{C}\right)$ exceeded the standard level during wet season. It could be the result of climatic condition because it was summer season. Temperature recorded in the Brahmaputra River water was $18.30^{\circ} \mathrm{C}$ during dry season and $29.43^{\circ} \mathrm{C}$ during wet season (Islam et al. 2015a), which are mostly similar to the present study. Yasmeen et al. (2012) found that the temperature of Buriganga River water in dry season complies with standard, which was found around 21.9 to $22.4^{\circ} \mathrm{C}$; whereas in wet season, it was around 31 to $33^{\circ} \mathrm{C}$, exceed the standard limit $\left(20\right.$ to $\left.30^{\circ} \mathrm{C}\right)$ set by $\mathrm{DoE}(2016)$.

Electrical conductivity (EC): The EC contents ranged 66.4 to 70.3 and 510.6 to $565.3 \mu \mathrm{S} / \mathrm{cm}$ during wet and dry season, respectively with an average $297.41 \mu \mathrm{S} / \mathrm{cm}$ in the Korotoa River. During wet season, the highest content of EC $(70.3 \mu \mathrm{S} / \mathrm{cm})$ was found at St-1 and the lowest $(66.4 \mu \mathrm{S} / \mathrm{cm})$ was at St-5. During dry season, the highest EC content $(565.3 \mu \mathrm{S} / \mathrm{cm})$ was found at St-2 and the lowest $(510.6 \mu \mathrm{S} / \mathrm{cm})$ was at St-1 (Fig. 2). The EC content of all the stations during dry season was higher than the wet season. According to DoE (2016) the standard of EC 


\section{WATER QUALITY AND FISH DIVERSITY IN KOROTOA RIVER}

for fisheries is $1200 \mu \mathrm{S} / \mathrm{cm}$ while the EC content of Korotoa River was less than the standard limit during both wet and dry season which indicated that the water was more or less suitable for fisheries production. Islam et al. (2015b) found the mean EC content in the Tista River water 84 and $145 \mu \mathrm{S} / \mathrm{cm}$ during wet and dry season, respectively which was more or less similar with the present study. Average EC content of Korotoa River varied from 171 to $471 \mu \mathrm{S} / \mathrm{cm}$ which was within the EQS limit in 2015 and it varied from 107 to $729 \mu \mathrm{S} / \mathrm{cm}$ in 2014 (DoE 2016). The average electrical conductivity was $280 \mu \mathrm{S} / \mathrm{cm}$ with a range from 190 to $420 \mu \mathrm{S} / \mathrm{cm}$ for water collected from the Korotoa River (Proshad et al. 2018).

Table II. Water quality parameters of the Korotoa River in wet and dry season

\begin{tabular}{|c|c|c|c|c|c|c|}
\hline \multirow{2}{*}{ Parameter } & \multirow{2}{*}{ Stations } & \multicolumn{2}{|c|}{ Wet season } & \multicolumn{2}{|c|}{ Dry season } & \multirow{2}{*}{ Standard } \\
\hline & & Avg. $(\mathrm{N}=3)$ & Range & Avg. $(\mathrm{N}=3)$ & Range & \\
\hline \multirow{6}{*}{$\begin{array}{l}\text { Temperature } \\
\left({ }^{\circ} \mathrm{C}\right)\end{array}$} & St-1 & 32.36 & \multirow{6}{*}{$\begin{array}{c}32.10 \\
\text { to } \\
32.60\end{array}$} & 19.20 & \multirow{6}{*}{$\begin{array}{c}19.20 \\
\text { to } \\
19.90\end{array}$} & \multirow{6}{*}{$\begin{array}{c}20-30 \\
(\mathrm{DoE} 2016)\end{array}$} \\
\hline & St-2 & 32.60 & & 19.80 & & \\
\hline & St-3 & 32.13 & & 19.50 & & \\
\hline & St-4 & 32.60 & & 18.90 & & \\
\hline & St-5 & 32.10 & & 19.40 & & \\
\hline & Mean \pm SD & $32.35 \pm 0.33$ & & $19.36 \pm 1.39$ & & \\
\hline \multirow{6}{*}{$\begin{array}{l}\mathrm{DO} \\
(\mathrm{mg} / \mathrm{L})\end{array}$} & St-1 & 2.0 & \multirow{6}{*}{$\begin{array}{c}2.0 \\
\text { to } \\
3.5\end{array}$} & 1.2 & \multirow{6}{*}{$\begin{array}{l}1.2 \\
\text { to } \\
2.1\end{array}$} & \multirow{6}{*}{$\begin{array}{c}\geq 5.0 \\
(\text { DoE 2016) }\end{array}$} \\
\hline & St-2 & 3.1 & & 1.5 & & \\
\hline & St-3 & 2. 1 & & $1 \%$ & & \\
\hline & St-4 & 3.5 & & 1.8 & & \\
\hline & St-5 & 3.2 & & 2.1 & & \\
\hline & Mean \pm SD & $2.78 \pm 0.68$ & & $1.56 \pm 0.39$ & & \\
\hline \multirow{6}{*}{$\begin{array}{l}\text { BOD } \\
(\mathrm{mg} / \mathrm{L})\end{array}$} & St-1 & 3.70 & \multirow{6}{*}{$\begin{array}{c}2.80 \\
\text { to } \\
3.70\end{array}$} & 1.90 & \multirow{6}{*}{$\begin{array}{c}1.73 \\
\text { to } \\
2.00\end{array}$} & \multirow{6}{*}{$\begin{array}{c}6.0 \\
(\text { DoE 2016) }\end{array}$} \\
\hline & St-2 & 3.20 & & 1.93 & & \\
\hline & St-3 & 3.70 & & 2.00 & & \\
\hline & St-4 & 2.80 & & 1.73 & & \\
\hline & St-5 & 3.40 & & 1.90 & & \\
\hline & Mean \pm SD & $3.36 \pm 0.37$ & & $1.91 \pm 0.48$ & & \\
\hline \multirow{5}{*}{$\begin{array}{l}\text { Alkalinity } \\
(\mathrm{mg} / \mathrm{L})\end{array}$} & St-1 & 82.66 & \multirow{5}{*}{$\begin{array}{c}50.66 \\
\text { to } \\
82.66\end{array}$} & 207.3 & \multirow{5}{*}{$\begin{array}{c}140.00 \\
\text { to } \\
207.30\end{array}$} & \multirow{5}{*}{$\begin{array}{c}150 \\
(\mathrm{DoE} 2016)\end{array}$} \\
\hline & St-2 & 63.00 & & 193.3 & & \\
\hline & St-3 & 68.66 & & 187.3 & & \\
\hline & $\begin{array}{l}\text { St-4 } \\
\text { St-5 }\end{array}$ & $\begin{array}{l}64.66 \\
50.66\end{array}$ & & $\begin{array}{l}103.0 \\
140.0\end{array}$ & & \\
\hline & Mean \pm SD & $65.92 \pm 11.51$ & & $178.18 \pm 26.68$ & & \\
\hline \multirow{6}{*}{$\begin{array}{l}\text { Acidity } \\
(\mathrm{mg} / \mathrm{L})\end{array}$} & St-1 & 2.30 & \multirow{6}{*}{$\begin{array}{c}2.30 \\
\text { to } \\
3.86\end{array}$} & 2.83 & \multirow{6}{*}{$\begin{array}{c}2.33 \\
\text { to } \\
4.16\end{array}$} & \multirow{6}{*}{-} \\
\hline & St-2 & 3.16 & & 3.16 & & \\
\hline & St-3 & 3.56 & & 2.33 & & \\
\hline & St-4 & 3.86 & & 3.66 & & \\
\hline & St-5 & 3.83 & & 4.16 & & \\
\hline & Mean \pm SD & $3.34 \pm 0.64$ & & $3.22 \pm 0.61$ & & \\
\hline \multirow{6}{*}{$\begin{array}{l}\text { Total hardness } \\
(\mathrm{mg} / \mathrm{L})\end{array}$} & St-1 & 112.0 & \multirow{6}{*}{$\begin{array}{c}75.33 \\
\text { to } \\
112.00\end{array}$} & 63.33 & & \\
\hline & St-2 & 88.66 & & 51.33 & & \\
\hline & St-3 & 110.66 & & 74.66 & 46.66 & 123 \\
\hline & St-4 & 75.33 & & 52.66 & to & (Huq and Alam \\
\hline & St-5 & 80.66 & & 46.66 & & \\
\hline & Mean \pm SD & $93.46 \pm 16.99$ & & $57.72 \pm 11.26$ & & \\
\hline
\end{tabular}




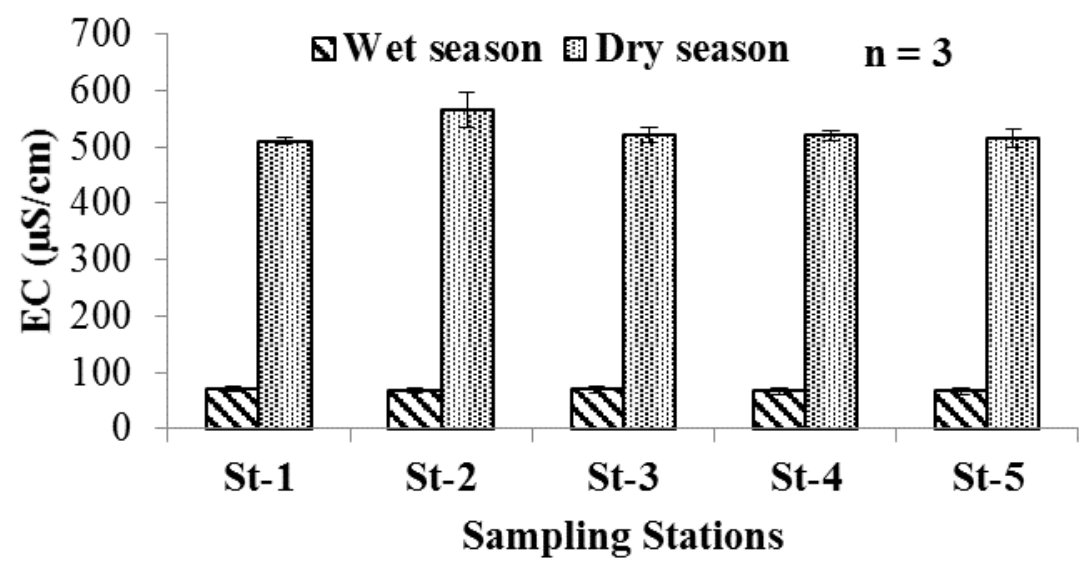

Fig. 2. The EC contents of the Korotoa River water during wet and dry season.

Total dissolved solid (TDS): The mean content of TDS was $98.86 \mathrm{mg} / \mathrm{L}$. In wet season, the highest content of TDS $(41.66 \mathrm{mg} / \mathrm{L})$ was found at St-2 and the lowest $(37.33 \mathrm{mg} / \mathrm{L})$ was at St1. The highest TDS $(159.66 \mathrm{mg} / \mathrm{L})$ was found at St-4 and the lowest $(155.66 \mathrm{mg} / \mathrm{L})$ was at St-1 and St-5 in dry season (Fig. 3). The standard level of TDS for fisheries is $2100 \mathrm{mg} / \mathrm{L}$ (DoE 2016). The mean content of TDS of all the stations was within the standard limit. Rehnuma et al. (2016) found the mean TDS content in the Bangshi River water 100 and $487.3 \mathrm{mg} / \mathrm{L}$ during wet and dry season, respectively which were comparatively higher than the present study. The TDS concentration of Korotoa River varied from 90 to $270 \mathrm{mg} / \mathrm{L}$ in 2015 , whereas it ranged from 110 to $370 \mathrm{mg} / \mathrm{L}$ in 2014 (DoE 2016).

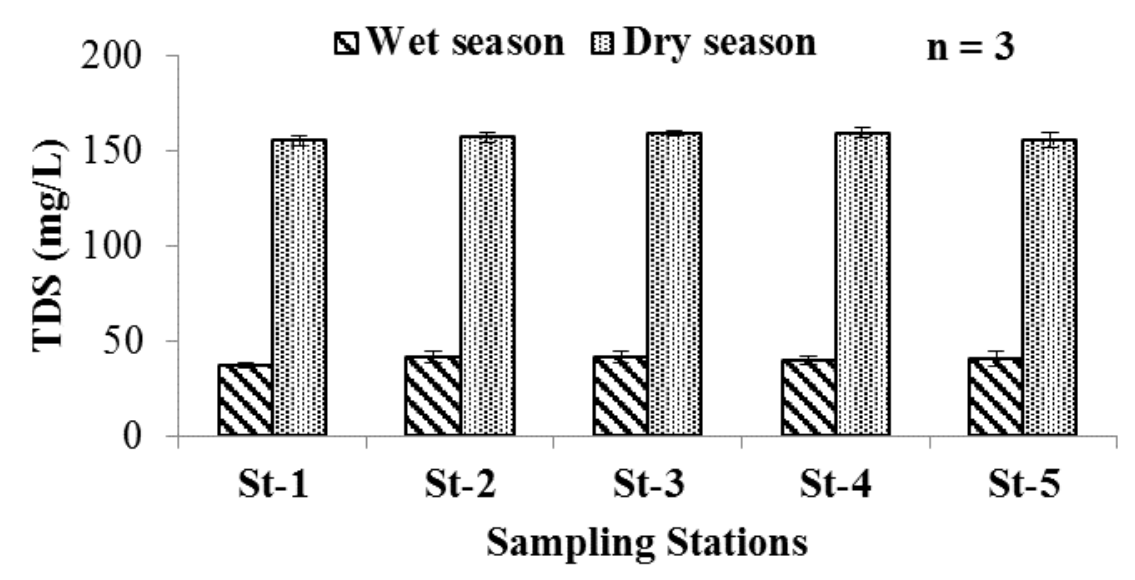

Fig. 3. The TDS contents of the Korotoa River water during wet and dry season. 
WATER QUALITY AND FISH DIVERSITY IN KOROTOA RIVER

Dissolved oxygen (DO): The average DO concentration was $2.17 \mathrm{mg} / \mathrm{L}$ during the study period which was less than the standard (DoE 2016). In wet season, the highest DO concentration (3.5 $\mathrm{mg} / \mathrm{L})$ was found at St-4 and the lowest $(2.0 \mathrm{mg} / \mathrm{L})$ was at St-1. The highest DO concentration $(2.1 \mathrm{mg} / \mathrm{L})$ was found at St-5 and the lowest $(1.2 \mathrm{mg} / \mathrm{L})$ was at St-1 and St-3 in dry season (Table II). Adequate DO is necessary for good water quality, survival of aquatic organism and decomposition of waste by microorganism (Islam et al. 2010). All the observed values including the average concentration were much lower than the DoE (2016) standard limit ( $\geq 5 \mathrm{mg} / \mathrm{L})$ for fisheries. This lower level observed could be due to agricultural slurry and surface runoff of nutrients. The lower DO concentrations indicate higher level of organic pollutants and lower level of oxygen concentration in water (Islam et al. 2012). The DO content of Korotoa River water was within the EQS limit $(>5 \mathrm{mg} / \mathrm{L}$ ) for fisheries. The DO content varied from 0.0 to $8.18 \mathrm{mg} / \mathrm{L}$ in 2015 and 2.0 to $6.8 \mathrm{mg} / \mathrm{L}$ in 2014 (DoE 2016).

Biological oxygen demand (BOD): During wet season, the highest BOD $(3.7 \mathrm{mg} / \mathrm{L})$ was found at St-1 and St-3, and the lowest $(2.8 \mathrm{mg} / \mathrm{L})$ was at St-4 (Table II). The highest $(2.0 \mathrm{mg} / \mathrm{L})$ BOD content was found at St-3 and the lowest $(1.73 \mathrm{mg} / \mathrm{L})$ was at St-4 during dry season. According to DoE (2016) standard, BOD for fisheries is $6.0 \mathrm{mg} / \mathrm{L}$. The average $(2.64 \mathrm{mg} / \mathrm{L})$ BOD content was much lower than the standard limit. When BOD level is high, DO level decrease because the oxygen available in water is consumed by bacteria (Sawyer et al. 2003). The minimum BOD of Korotoa River was $2.1 \mathrm{mg} / \mathrm{L}$ in August and the maximum was $7.5 \mathrm{mg} / \mathrm{L}$ in January in 2015 whereas it varied from 1.5 to $6.4 \mathrm{mg} / \mathrm{L}$ in 2014 (DoE 2016).

Alkalinity. The highest alkalinity $(82.66 \mathrm{mg} / \mathrm{L})$ was found at St-1 and the lowest $(50.66 \mathrm{mg} / \mathrm{L})$ was at St-5 during wet season. In dry season, the highest alkalinity $(207.3 \mathrm{mg} / \mathrm{L})$ was found at St-1 and the lowest $(140 \mathrm{mg} / \mathrm{L})$ was at St-5 (Table II). The mean alkalinity of the Korotoa River water was $122.05 \mathrm{mg} / \mathrm{L}$ which was within the DoE (2016) standard limit $(150 \mathrm{mg} / \mathrm{L})$. Islam et al. (2014) found more alkalinity in water of Brahmaputra River during dry season, due to the river banks were widely used for agricultural practices and most of the crops were harvested during this season.

Acidity. Acidity describes the amount of acid in a substance. During wet season, the highest acidity $(3.86 \mathrm{mg} / \mathrm{L})$ was found at St-4 and the lowest $(2.30 \mathrm{mg} / \mathrm{L})$ was at St-1. The highest acidity $(4.16 \mathrm{mg} / \mathrm{L})$ was found at St-5 and the lowest $(2.33 \mathrm{mg} / \mathrm{L})$ was at St-3 in dry season (Table II). The average acidity of the Korotoa River water was $3.28 \mathrm{mg} / \mathrm{L}$. There is no information documented about the concentration of acidity in the Korotoa River.

Total hardness: Total hardness is a measurement of the mineral content in a water sample that is irreversible by boiling. Total hardness is determined by the multivalent cations' concentrations present in water. General guidelines for classification of waters are: 0 to $60 \mathrm{mg} / \mathrm{L}$ as calcium carbonate is classified as soft; 61 to $120 \mathrm{mg} / \mathrm{L}$ as moderately hard; 121 to $180 \mathrm{mg} / \mathrm{L}$ as hard; and more than $180 \mathrm{mg} / \mathrm{L}$ as very hard. During wet season, the highest content of total hardness $(112.00 \mathrm{mg} / \mathrm{L})$ was found at St-1 and the lowest content $(75.33 \mathrm{mg} / \mathrm{L}$ ) was found at St-4 (Table II). The highest content of total hardness $(74.67 \mathrm{mg} / \mathrm{L})$ was found at St-3 and the lowest content $(46.67 \mathrm{mg} / \mathrm{L})$ was found at St-5 in dry season. Mean content of hardness $(75.59 \mathrm{mg} / \mathrm{L})$ in the river water was within standard level during both the seasons according to Huq and Alam (2005). 
Comparison of water quality parameters: The highest DO was found in Passur River followed by Padma, Dhaleswari and Pungli River (Table III). Only the DO content in Tista River (5.36 $\mathrm{mg} / \mathrm{L}$ ) was found suitable for fisheries and similar to the EQS of DoE (2016). The DO content revealed that the Buriganga River is much polluted than the others, and the Korotoa River water is not suitable for fish and other aquatic organisms. The alkalinity of Korotoa River was found within the standard level. The water quality of major rivers viz. Padma, Meghna, Jamuna, Dhaleshwari, Surma, Korotoa, etc. was within the limit of EQS in 2015 while rivers around greater Dhaka were highly polluted in terms of DO and BOD (DoE 2016). During dry season, river water quality become worse, on the contrary, its quality improved greatly during wet season indicating clear relationship between increase river flow and water quality (DoE 2016).

Table III. Comparison of water qualities of present study with those of previous studies

\begin{tabular}{|c|c|c|c|c|c|c|c|}
\hline \multirow[b]{2}{*}{ Rivers } & \multicolumn{6}{|c|}{ Physicochemical parameters of river water } & \multirow[b]{2}{*}{ References } \\
\hline & $\begin{array}{c}\text { Temp. } \\
\left({ }^{\circ} \mathrm{C}\right)\end{array}$ & $\begin{array}{c}\mathrm{EC} \\
(\mu \mathrm{S} / \mathrm{cm})\end{array}$ & $\begin{array}{c}\text { TDS } \\
(\mathrm{mg} / \mathrm{L})\end{array}$ & $\begin{array}{c}\mathrm{DO} \\
(\mathrm{mg} / \mathrm{L})\end{array}$ & $\begin{array}{c}\text { Alkalinity } \\
(\mathrm{mg} / \mathrm{L})\end{array}$ & $\begin{array}{c}\text { Hardness } \\
(\mathrm{mg} / \mathrm{L})\end{array}$ & \\
\hline Korotoa & 25.86 & 297.41 & 98.86 & 2.17 & 122.05 & 75.60 & Present study \\
\hline Meghna & 19.3 & 659 & 150.4 & 3.63 & NA & 114.6 & $\begin{array}{l}\text { Begum et al. } \\
\text { (2019) }\end{array}$ \\
\hline Gowain & 30.7 & 74 & 39.42 & 4.82 & 210.5 & 108.9 & $\begin{array}{l}\text { Nahian et al. } \\
\quad(2018)\end{array}$ \\
\hline Shitalakhya & 31.48 & 925 & 435.67 & 2.16 & 295.50 & 76.15 & $\begin{array}{l}\text { Irin } \text { et al. } \\
\text { (2016) }\end{array}$ \\
\hline Bangshi & 25.9 & 483 & 293.25 & 3.28 & 201.5 & NA & $\begin{array}{l}\text { Rehnuma et } \\
\text { al. (2016) }\end{array}$ \\
\hline Tista & 22.02 & 115 & 63.53 & 5.36 & 42.17 & 100.47 & $\begin{array}{l}\text { Islam et al. } \\
\quad(2015 \mathrm{a})\end{array}$ \\
\hline Brahmaputra & 23.38 & 351 & 178.54 & 4.47 & 98.63 & 82.36 & $\begin{array}{l}\text { Islam et al. } \\
\quad(2015 \mathrm{~b})\end{array}$ \\
\hline Padma & 28.33 & 230 & 149.66 & 7.24 & 168.66 & 68.33 & $\begin{array}{l}\text { Islam et al. } \\
\text { (2014) }\end{array}$ \\
\hline Passur & 25.75 & 10120 & 5046.75 & 11.73 & 189.25 & 383.08 & $\begin{array}{l}\text { Shil et al. } \\
\text { (2014) }\end{array}$ \\
\hline Turag & 27.02 & 661.83 & 358.96 & 2.58 & 378.33 & 114.83 & $\begin{array}{l}\text { Meghla et al. } \\
\quad \text { (2013) }\end{array}$ \\
\hline Pungli & 29.23 & 346.06 & 178.10 & 6.36 & 454.50 & 40.23 & $\begin{array}{l}\text { Suravi et al. } \\
\quad \text { (2013) }\end{array}$ \\
\hline Dhaleswari & 29.03 & 319.43 & 173.10 & 6.46 & 351.06 & 41.23 & $\begin{array}{l}\text { Islam et al. } \\
\quad \text { (2012) }\end{array}$ \\
\hline Jamuna & 34.26 & 123 & 119.76 & 3.00 & NA & NA & $\begin{array}{l}\text { Bhattacharjee } \\
\text { et al. (2012) }\end{array}$ \\
\hline Buriganga & 22.15 & 924 & 372.75 & 0.55 & 203.50 & NA & $\begin{array}{l}\text { Yasmeen et } \\
\text { al. (2012) }\end{array}$ \\
\hline Standard & $20-30$ & 1200 & 2100 & $>5.00$ & 150 & $\mathrm{Nd}$ & DoE (2016) \\
\hline
\end{tabular}

Fish diversity: A total of seventy individuals of fish were counted and categorized during the study period at Korotoa River (Table IV). Among those, ten species were found which belong to ten genera, seven families and five orders. Cypriniformes was found as the most dominant order considering species variety and abundance, Siluriformes and Perciformes occupied second and third position in abundance, respectively. During investigation, four species from Cyprinidae family under the order Cypriniformes were recorded which consist $40 \%$ of species diversity and $44.29 \%$ of fish individuals. Two species of Siluriformes from two families i.e. 
WATER QUALITY AND FISH DIVERSITY IN KOROTOA RIVER

Heteropneustidae and Bagridae were recorded which consist $21.43 \%$ of the total fish population in numbers and $20 \%$ regarding species diversity. In case of Perciformes, two species belong to two families viz. Gobiidae and Osphronemidae were found during the study period which consist $20 \%$ of species diversity and $15.71 \%$ of fish individuals.

Table IV. Fish diversity of the Korotoa River with their present status

\begin{tabular}{|c|c|c|c|c|c|}
\hline Order & Family & Local name & English name & Scientific name & Status \\
\hline \multirow[t]{4}{*}{ Cypriniformes } & Cyprinidae & Mola & Indian carplet & $\begin{array}{l}\text { Amblypharyngodon } \\
\text { microlepis }\end{array}$ & NO \\
\hline & & Mrigal & Mrigal & Cirrhinus cirrhosus & NL \\
\hline & & Kalbasu & Black rohu & Labeo calbasu & EN \\
\hline & & Punti & Pool barb & Puntius sophore & NO \\
\hline \multirow[t]{2}{*}{ Perciformes } & Gobiidae & Bele & Tank goby & Glossogobius giuris & NO \\
\hline & Osphronemidae & Lal khailsha & Dwarf gourami & Colisa lalia & NO \\
\hline \multirow[t]{2}{*}{ Siluriformes } & Heteropneustidae & Shing & Stinging catfish & Heteropneustes fossils & NO \\
\hline & Bagridae & Bajaritengra & Stripped catfish & Mystus tengara & NO \\
\hline Channiformes & Channidae & Taki & Spotted snakehead & Channa punctatus & NO \\
\hline Beloniformes & Belonidae & Kankila & Freshwater garfish & Xenentodon cancila & NO \\
\hline
\end{tabular}

Note: IUCN Red List (2015) status, EN: Endangered, NO: Not threatened, NL: Not listed.

The lowest number of species was counted for the order Channiformes and Beloniformes which consist $11.43 \%$ and $7.14 \%$ of the total fish population in number, respectively. Only one species was obtained during the period of investigation for each of the two orders consist $10 \%$ of species diversity. Those fish species were Channa punctatus and Xenentodon cancila belong to the family Channidae and Belonidae, respectively (Table IV and Fig. 4). Out of the collected ten species, eight species were not threatened (NO). Among rest of the two fish species, one species (Labeo calbasu) ranked as endangered (EN) and another one not listed (NL) according to IUCN (2015).

\section{Fisheries resources}

Present status of Korotoa River: From the study it was found that the present condition of Korotoa River is not good enough. Maximum respondents (60\%) argued that the present condition of the river is not good due to manifold reasons like agricultural encroachment with other anthropogenic activities which results narrowing the river and its water flow (Table V). About $30 \%$ of respondents said the river condition is good and $10 \%$ of respondents argued that the river condition is better than the past due to dragging and awareness of people about the river pollution.

Present status of fish diversity. The Korotoa River is an important source for fish production in northwest Bangladesh. It is one of the sources of income for many fishermen living besides it. But at present day the river and its fish diversity are in critical condition revealed by the respondents. Most of the respondents about $66 \%$ of respondents argued that the condition of fish diversity is not good than past due to fertilizer and pesticides application in agricultural land 
along with urbanization and $18 \%$ of respondents reported that the condition of fish diversity is good and $16 \%$ of respondents said that the condition is better than the past (Table V).

Table V. Stakeholders' perception about the Korotoa River, its water quality and fisheries resources

\begin{tabular}{|c|c|c|c|}
\hline & Variables & Frequency $(n=50)$ & $\begin{array}{c}\text { Percentage } \\
(\%)\end{array}$ \\
\hline & Present status of Korotoa River & & \\
\hline 1. & Good & 15 & 30 \\
\hline 2. & Better & 5 & 10 \\
\hline \multirow[t]{2}{*}{3.} & Not good & 30 & 60 \\
\hline & Present status of fish diversity & & \\
\hline 1. & Good & 9 & 18 \\
\hline 2. & Better & 8 & 16 \\
\hline \multirow[t]{2}{*}{3.} & Not good & 33 & 66 \\
\hline & Availability of fish species in Korotoa River & & \\
\hline 1. & High & 2 & 4 \\
\hline 2. & Medium & 18 & 36 \\
\hline \multirow[t]{2}{*}{3.} & Low & 30 & 60 \\
\hline & Change in availability of fish species & & \\
\hline 1. & Slight increase & 9 & 18 \\
\hline 2. & Drastic increase & 0 & 0 \\
\hline 3. & Slight decrease & 16 & 32 \\
\hline \multirow[t]{2}{*}{4.} & Drastic decrease & 25 & 50 \\
\hline & Causes of fish diversity loss & & \\
\hline 1. & Agricultural encroachment & 9 & 18 \\
\hline 2. & Siltation & 3 & 6 \\
\hline 3. & Water quality degradation & 23 & 46 \\
\hline \multirow[t]{2}{*}{4.} & All of them & 15 & 30 \\
\hline & Causes of water quality degradation & & \\
\hline 1. & Waste dumping & 29 & 58 \\
\hline 2. & Urbanization & 8 & 16 \\
\hline 3. & River bank erosion & 4 & 8 \\
\hline 4. & All of them & 9 & 18 \\
\hline
\end{tabular}

Availability of fish species: The availability of fisheries resources in Korotoa River is lower than past revealed by $60 \%$ of respondents and $36 \%$ of respondents said the availability is medium than past. On the other hand only $4 \%$ of respondents said the availability of fish is more or less higher than the past (Table V).

Change in availability of fish species: According to the respondents, once upon a time the Korotoa River was full of fishes, and many fishermen used to lead their life depending on Korotoa River. But now a day's rarely some fishes are captured. About $50 \%$ of respondents said that fishes were drastically decreased than past whereas $32 \%$ of respondents said that fishes have slightly decreased whereas $18 \%$ of respondents reported slightly increased than the past (Table V). 
WATER QUALITY AND FISH DIVERSITY IN KOROTOA RIVER

Causes of loss of fisheries resource: There are many causes for loss of fisheries resource of the Korotoa River. But some key causes like agricultural encroachment, siltation and water quality degradation are revealed by the respondents in survey. About $46 \%$ of respondents revealed that the key cause of loss of fisheries resource is water quality degradation, $18 \%$ of respondents said the key cause is agricultural encroachment, $6 \%$ of respondents reported about siltation, and on the other hand $30 \%$ of respondents said all of them are the key causes of fish diversity loss (Table V).

Causes of water quality degradation: The most notable causes of water quality degradation in Korotoa River revealed by survey are waste dumping, urbanization, river bank erosion and all of them. About $66 \%$ of respondents argued that the principal cause of water quality degradation is waste dumping into the river, $16 \%$ of respondents said urbanization alongside river and $18 \%$ of respondents said all of them (Table V). Water quality degradation is the key cause of fisheries resource loss revealed by the respondents.

\section{Conclusions}

The study found that the Korotoa River water was not completely safe and was polluted to certain extents which arose from different kinds of human activities like excess agricultural practice, waste dumping, and silt collection from the river side, etc. As a result of water quality problem, fish species are losing their habitats. Water quality degradation along with agricultural encroachment and waste dumping are the main causes of loss of fisheries resources of Korotoa River. If this condition is continuously going on, one day, the river will lose its existence and production capabilities. To maintain sound aquatic environment and healthy ecosystem of the Korotoa River, appropriate steps must be taken.

\section{Literature Cited}

Begum, S., M.S. Islam, M. Rehnuma, M.H. Kabir and T.R. Tusher, 2019. Water quality and fish diversity status in Meghna River at Narsingdi in Bangladesh. Bangladesh J. Environ. Sci., 37: 25-31.

Bhattacharjee, U., M.S. Islam, M.E. Hoq, Suravi and N.T. Meghla, 2012. Studies on water quality of the river Jamuna at Bhuapur in Tangail region. Bangladesh J. Fish. Res., 15-16: 59-68.

Carpenter, K.E. and V.H. Niem, 1998. FAO species identification guide for fishery purposes. The living marine resources of the western central pacific. Volume-2: cephalopods, crustaceans, holothurians and sharks. FAO, Rome, Italy, 687-1367.

DoE (Department of Environment), 2016. River water quality report 2015, Environmental Quality Standard, Natural Resource Management Section, Department of Environment, Ministry of Environment and Forests, Government of the People's Republic of Bangladesh, Dhaka, Bangladesh, $64 \mathrm{p}$.

Galib, S.M., S.M.A. Naser and A.B.M. Mohsin, 2013. Fish biodiversity of river Choto Jamuna, Bangladesh: present status and conservation needs. Int. J. Biodiver., Conserv., 5(6): 389-395.

Hasan, M.K., M.R.I. Khan, M.K. Nesha and M.A. Happy, 2014. Analysis of water quality using chemical parameters and metal status of Balu River at Dhaka, Bangladesh. Open J. Water Pollut. Treat., 1(2): 58-74.

Hasan, S.J., M.B. Tanu, M.I. Haider, T. Ahmed and A.S.A. Rubel, 2015. Physicochemical characteristics and accumulation of heavy metals in water and sediments of the river Dakatia, Bangladesh. Int. J. Fish. Aquat. Stud., 2(5): 300-304.

Huq, S.M.I. and M.D. Alam, 2005. A handbook on analysis of soil, plant and water. BACER-DU, University of Dhaka, Bangladesh, $265 \mathrm{p}$. 
Irin, A., M.S. Islam, M.H. Kabir and M.E. Hoq, 2016. Heavy metal contamination in water and fishes from the Shitalakhya River at Narayanganj, Bangladesh. Bangladesh J. Zool., 44(2): 267-273.

Islam, M.S. M.A. Islam, M.J. Islam, M.H. Kabir and N.T. Meghla, 2015a. Status of water quality in the Tista River at Kaunia point and its impact on aquatic environment. J. Environ. Sci. Nat. Resour., 8(1): 29-33.

Islam, M.S., M.A. Islam, N.A. Sweety, M.A.R. Hossain and M.H. Kabir, 2016. Assessment of aquatic faunal diversity in the Ratargul swamp forest at Sylhet in Bangladesh. J. Environ. Sci. Nat. Resour., 9(2): 51-64.

Islam, M.S., M.H. Kabir, S.A. Sifat, N.T. Meghla and T.R. Tusher, 2014. Status of water quality from the Padma River at Bheramara point of Kushtia in Bangladesh. Bangladesh J. Environ. Sci., 27: 110115.

Islam, M.S., N.T. Meghla, Suravi, M. Islam and N. Sultana, 2012. Status of water quality in the Dhaleswari River and its effect on aquatic organisms. Bangladesh J. Environ. Sci., 23: 131-138.

Islam, M.S., Suravi and N.T. Meghla, 2010. Investigation on water quality in Ashulia Beel, Dhaka. Bangladesh J. Fish. Res., 14(1-2): 55-64.

Islam, M.S., T. Datta, I.J. Ema, M.H. Kabir and N.T. Meghla, 2015b. Investigation of water quality from the Brahmaputra River in Sherpur district. Bangladesh J. Sci. Res., 28(1): 35-41.

IUCN (International Union for Conservation of Nature) Bangladesh, 2015. Red List of Bangladesh Volume 5: Freshwater Fishes. IUCN, International Union for Conservation of Nature, Bangladesh Country Office, Dhaka, Bangladesh, 360 p.

Khan, M.A.R., M.I. Miah, M.B. Hossain, A. Begum, M.H. Minar and R. Karim, 2013. Fish biodiversity and livelihood status of fishing community of Tista River, Bangladesh. Global Vet. 10(4): 417-423.

Meghla, N.T., M.S. Islam, M.A. Ali, Suravi and N. Sultana, 2013. Investigation of physicochemical properties of water from the Turag River, Dhaka. Int. J. Curr. Microbiol. Appl. Sci., 2(5): 110-122.

Nahian, M., M.S. Islam, M.H. Kabir, T.R. Tusher and N. Sultana, 2018. Seasonal variation of water quality in Gowain River near Ratargul swamp forest, Sylhet, Bangladesh. Grassroots J. Nat. Resour., 1(1): 26-36.

Proshad, R., M.S. Islam, T. Kormoker, M.E.M. Masud and M.M. Ali, 2018. Assessment of toxic metals contamination with ecological risk of surface water and sediment of Korotoa River in Bangladesh. Int. J. Adv. Geosci., 6(2): 214-221.

Rahman, A.K.A., 2005. Freshwater fishes of Bangladesh, second edition, zoological society of Bangladesh, Dhaka, Bangladesh. 394 p.

Rehnuma, M., M.S. Islam, N.T. Meghla and M.H. Kabir, 2016. Investigation of water quality parameters from Bangshi River at Mirzapur in Bangladesh. J. Sci. Technol., 6(1-2): 153-160.

Rubel, M.R.I., S. Hashem, M.R. Hasan, S.M. Rahmatullah, K. Ferdousi and J.J. Bornali, 2014. Catch composition of fishes by using different types of fishing gear in Lohalia River of Bangladesh. Int. J. Res. Fish. Aquac., 4(4): 161-170.

Sayeed, M.A., S. Hashem, M.A. Salam, M.A.R Hossain and M.A. Wahab, 2014. Assessment of Chalan Beel ecosystem diversity through remote sensing and geographical information systems. Int. J. Innov. Appl. Stud., 7(1): 353-365.

Shil, S.C., M.S. Islam, M.E. Hoq, N.T. Meghla and L. Sarkar, 2014.Tidal influence on physicochemical parameters of water from the Mongla port near Sundarban mangroves in Bangladesh. Bangladesh $J$. Environ. Sci., 27: 142-149.

Suravi, M.S. Islam, M.A. Ali, N.T. Meghla and N. Sultana, 2013. Seasonal variations of water quality parameters from the Pungli River in Tangail region. Int. J. Curr. Microbiol. Appl. Sci., 2(5): 155167.

Yasmeen, S., M.S. Islam, M.A. Ahsan, M.H. Rahaman and N.T. Meghla, 2012. Assessment of water qualities in the Buriganga River of Dhaka city corporation area. Bangladesh J. Environ. Sci., 23: 151158. 